
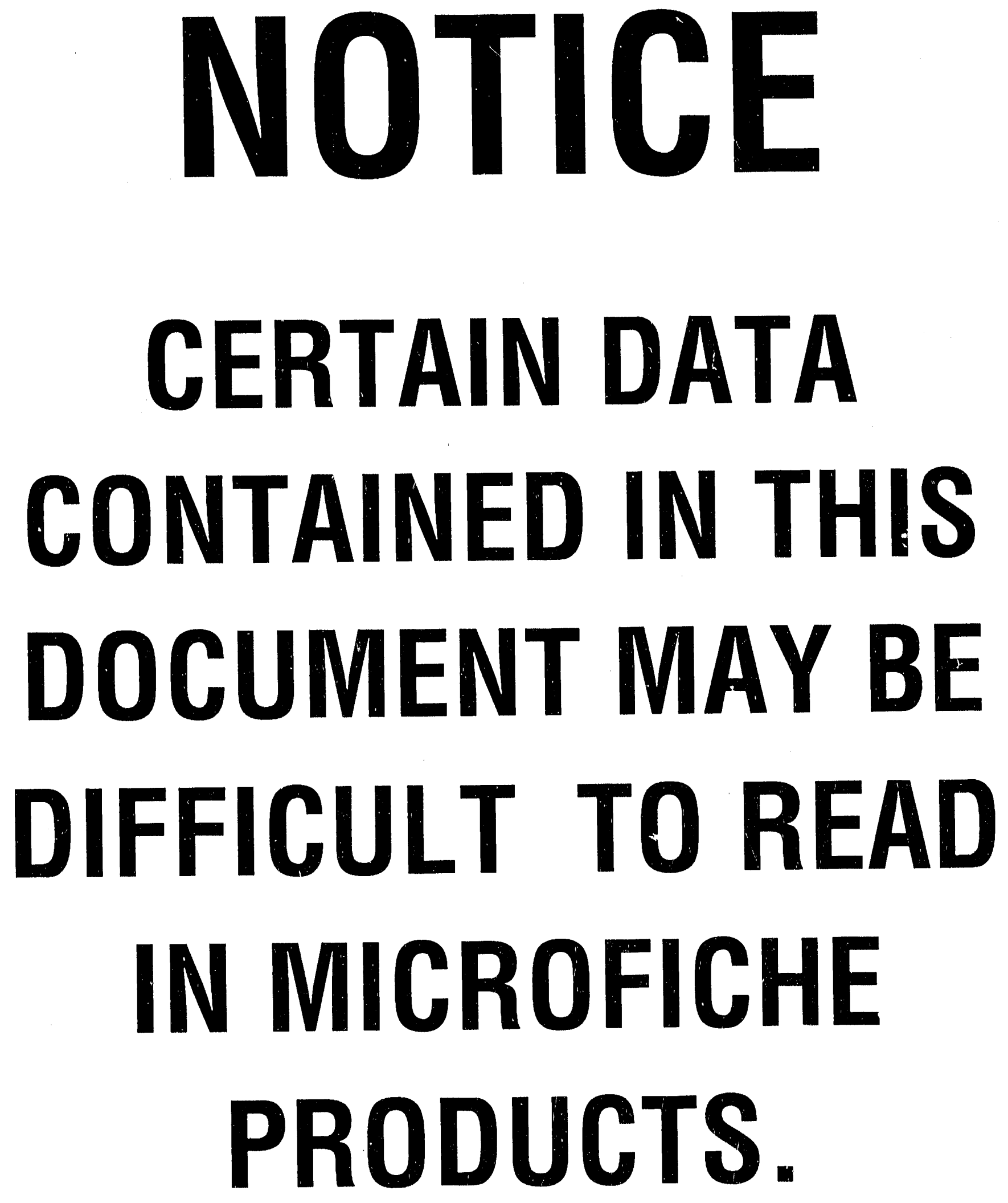

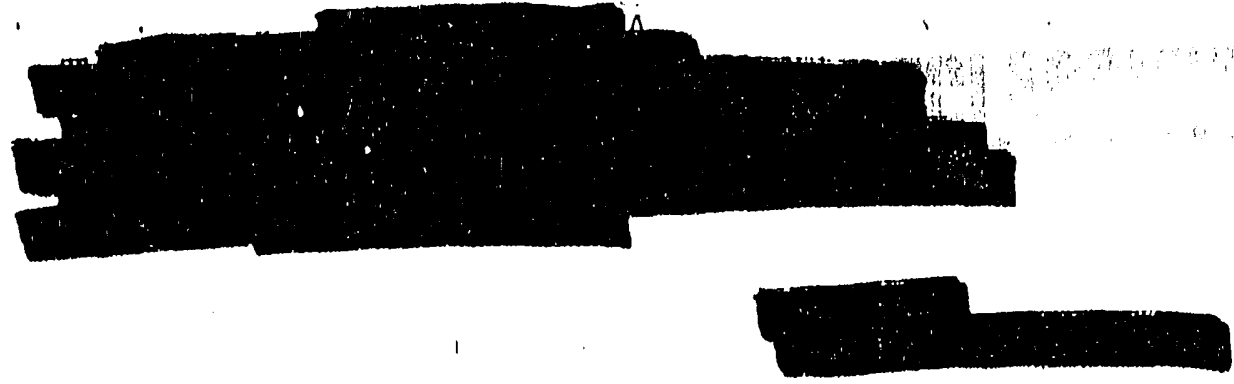

January 7,1953

"bis pocument, conais tse uf " Finget? -

$\mathrm{HAN}-\mathbf{4 8 4 2 2}$

DE92. 011314

CLASSTPLCAT!ON CANCFLLFD OR CHAitri. Hluclagen. BY AUTHI: . UF XLO- $\angle C_{2}$ BY(e) a drepdediTE $3-4-2)^{2}$ gorcegefery o3-5-72

\section{ATOMIO ENERTY COMMISGION}

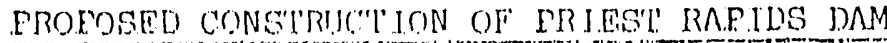 \\ IN RBILATION IO IIANFORI) WORKS}

Report by the Mrunges llanford operatlons orfleo

1

\section{THE TROBLEM}

1. To determine wholher tha rommlealon should oppose the construc... tion of the proposed Prinst, Paptas Dam in the Con Lumbla River.

\section{BACKGROSUND)}

2. For aeveral yeara the Prlant: Raplda linm hag been proposed by the Corps of Englneers na prit of the Integrated devalopment of the Colum. bia Rlver and the tribularlos. Ihe site is at. mlje 397 (from the moulh of the Columbia Rlyer) and is aboul, le mlelog nbove Hanford Works, pilant.

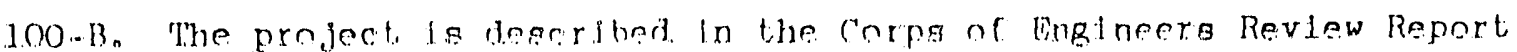
on the Columbla Rluer" and "Tlhularlor, Nprendix "p" (the "308 Report") dated ontober 1. 1948 . The dam in one or elphl construeted or proposed for the Columbia Rluer of thage nlpht, throe are completed (Bomnevilie.

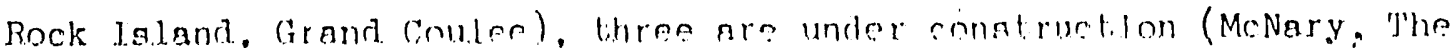
Dalleg, and. Chiof inseph), sud two nye proposed (John Iny and Priegt Rapida). The latter two are the only Columbla River dams whloh will inm clude flood rontrol pentures.

3. To date, demand for pniver in the Pacific Northweat, particularly for gluminum reduction, hag increaped. fagter than new power has been developed. 
EBOEDSED CONETRICL ION OF PRIEST RA.ETDS DAM

IN BELANCION ITO HIANFORD WORKS

Report by the Mrngger" llanfodd Operationg offlce

1

THE PROBLEM

1. To determine whetiher the Conmlesion should oppose the construc.tion of the proposed Fripst Raplda Dam in the CnLumbla River.

\section{RAC:KGROINND}

2. For aeveral yeara the Frtegt: Raplda Ram has been proposed by the Corps of Englneers an part of the Integrated devalopment of the Columm bia River and ita tribularieg. The stte is at. mile 397 (from the mouth of the Columbia River) and is about, 12 miles above Hanford Works, pilant. 100-B. The project is degeribed in the Corps of Engineerc Review Report on the Columbla Rlver and Tributarlos; Appenilix "F" (the "308 Report") dated October 1. 19h8n The dam is one of elght: constructed or proposed for whe Columbia Rlver, Or these elght, thren are completed (Bonnevilie, ' Rock latand, (Grand Coulee), three are under crnatruetion (McNary, The Dalles, and. Chlef inseph), and two are proposed (John Day and Priest Rapids). The latter two are the only Columbia River dams which will In-m clude flood control fenturas.

3. To date, demand for power in the Pactric Northwest, particularly for aluminum reduction, has increased fagter than new power has been developed.

a. The Columbia Basin Irrigation project, now nearing completion, w1.l bring a vast population increase intol the area lying just east of Prlest: Rapids and east of the exlsting privately-owned Rock

WhBSTER DISTRIBUTION RESTRLTEN 10 U.S. BMI

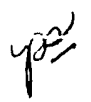

$1-$

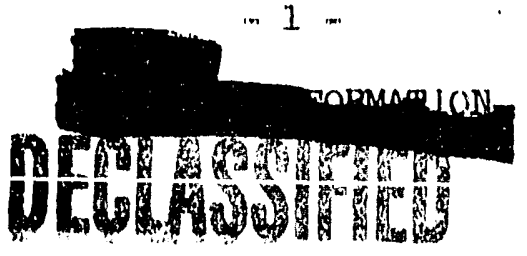

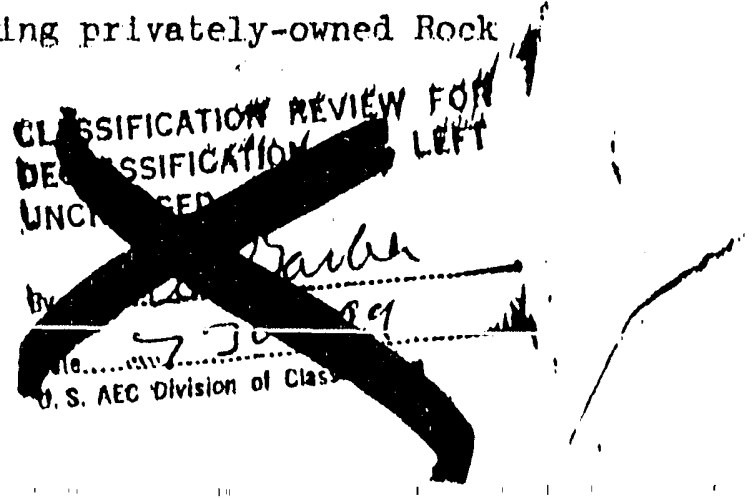


Island Dam, 60 miles upgtream from Frieat Raplds. Thls population w111 require additional power.

b. The Ice Uarbor and Lower Monumental dama, two of the four dams authorlzed for the lowor Snake Rlver, would be relatively close to the Columbla Irrigntion project area and to the Hanford Works. 4. The Frlegt: Raplda Dam has been proposed by the Corps of Eng1neers but has not yet been anthorlzed by Congresa. It can be expected that the Corps of Englnepra may raqueat authorization in the near future, since this and the John Day dam (at: mila 2ap) are the only remalning dams, of the elght mogor structures on the Columbla River, stili to be constructed. Roth will be flond control dnme. General Manager, M. W. Boyer, Indilcated the Commisalon's concern over the proposed dam in a let-

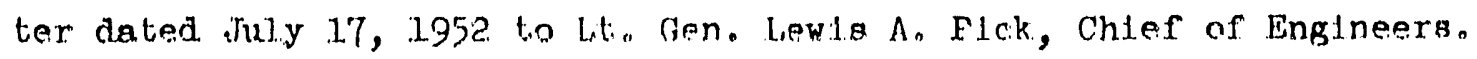
General. Plak replied to Mr. Boyar'a latier on iluly 31., 1952, saylng that the posalble effects on the HW would be considered and atating that no funds had yet been made avallabia for construction of the dam.

5. On July 22, 1952, Fubile IItility Diatricot \#2 of Grant County, with hegdquarters at Ephrata, Weshlngton, filed with the. Federal Power Commisalon an application for proliminary permit for conatruction of the Prlest Raptda Dam (FPC Frnjact 2114). Thlo appears to be a step toward providing power for the newly devaloped Columbla Pagln Irrigation project area. The FUD is relatilraly amall at present, but a market for the developed power seems assured in 1 ts territiory. This application could be a political move to atimulate the Corps of Enginsers to expedite ita planning on the dam, although there has been no avidance to thig effect. a. If the fun were to bulld the dam, 1.t would bulld a capaclty only for power requlramente. Added rapacity for flood control probably would have to be rtnenced by the Federel orevernment. The Corps of Engineers' plan provldes for a dam 13,500 feet long. The PUD dam would be lowern, and would be $11 ., 780$ long gt the same loca- 
4. The Frlegt; Rapidg Dam has been proposed by the Corps of Eng1neers but has not yet boen authorlyed by Congresa. It can be expected that the Corps of Englnepra mgy request alathorlzation in the near future, since this and the John. Day dam (ot: mile aso) are the only remaining dams, of the elght major atruetirea on the Columbla River, still to be constructed. Roth will be finod control dnms, General Manager, $M_{0} W_{n}$ Boyer, Indtcated the Commialon's concern over the proposed dam in a letter dated iruly 17, 1952 to Lto Gen. Lewla A. Flck, Chief of Englneers. General Plak replied to Mr. Boyar's latter on July 31., 1952, anying that the posalble effects on the HW would be coneldered and atating that no funda had yet been made avallable for conatruction of the dam.

5. On July 22, 1952, Fublice IIt111ty District \#2 of Grant County, with headquarters at Ephrata, Washington, f1.ed w1th the. Federal Power Compasaton an application for preliminary permit for construction of the Priegt Raplds Dam (FPC Prnject 21.14). This appears to be a sep toward providing power for the newly developed Columbla Rasin Irrigation project area. The PUD is relatirely small at present, but a market for the developed power eeems assured in 1 ts territory. This application could be a political move to atimulate the Corps of Englneers to expedite its planning on the dam, allhough there has been no evldence to this effect. B. If the FUD were to butid the dam, 1.t would bulld a capaclty only for power requilemente. Added capacity for flood control probably would have to be flnanced by the Federal Government. The Corps of Engineers' plan provides for a dam 13,500 feet long. The FUD dam would be lower, and would be 11,780 long at the same location.

6. The AEC owns, in fee slmple, a strip of land along the west bank of the Columbla River at Priest Rap1ds. This Irregular shaped tract varles 


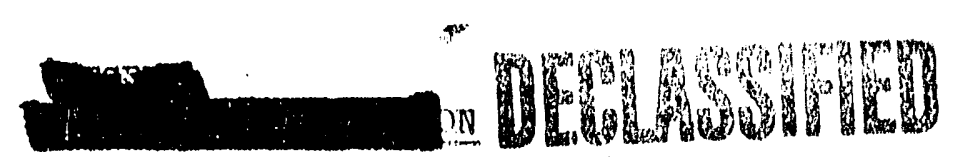

from 200 yards to more than a half mile in width, and extents for almost three mlles along the river bank. The Priest Raplda dam alte is about midway of the length of thl tract, and at that point 1. a gmall hydrow electrite plant now owned by the $A E C$ and nperated for the Commlaston under contract by the Paclfic Fower \& light Company. A.L. of that portion of the tract lying upstream from the pregent, power plant is requlred for the intake canal to the plant.

The remalnder of the land required for the actual dam atte, and for much of the pond area, to nkned by tha Waghlngton Irrigation and. Development Company。 Quite recently, the Corps of Engtneers fillad a Declaration of Thaking on most of the company's holdinge on the weat bank, as part of the Yakima Artillery Range. The Grant County F(ID has announced ith intention to acquilre the company's ramalning holdings by condermation in the state courts. Obvlougly becavge of the AEC's ownerghlp of the present hydroelectric plant tract, the Federal Government controls the dam alte.

7. The construction of the Frigat Raplda dam could create a critical hazard to the Hanford. Worka in case of enamy antion. A low dam, as proposed by the PUD, with more than one mile of earthmflil, would be easter to breach than would the Corps of Englneors' proposed dam, because of the smaller crogamgection of the earth-fill. The Cnrps of Englneers' dam, undar certaln clrcumatancea, could on the other hand have a far greater voluma of water which would be released by breaching. Elther type dam would compound the disgater which would result from breaching of Grand Coulee Dam (see Hanford Clasalfled Document Number 46604 , subjects "Fmergency Flanning for Disaster at Grand. Couleo Dam, Dated September 25, $\left.1.952^{\prime \prime}\right)$.

8. Because of the annnunced plans of the Mo for construction of the dam, and the antictpated plans of the Corpo of Englneers, the Commior

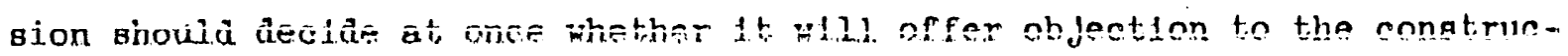
tion of a dam at Prlest Raplda. 


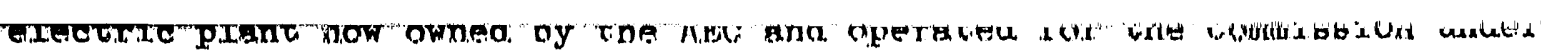
contract by tha Faclfic Fower \& Ingh Company. All. of that portion of the tract lying upstream firm the preaent power plant is required for the intake conel to the p.rant.

The remalnder of the land. requlred for the actugl dam alto, and for much of tihe ponl area. If nkned. by the Waghington Irrtgation and. Development Company. Quite recently, the Corps of Englneari filed a Decilaration of Taking on most of the company' kinldinga nn the wegt bank, ag part of the Yakima Artillery Range. The Grant County F(rL) has announced 1 tis In-tention to acquitre the company's remalning holdings by condemnation in the State courta. Obviougly because of the ARC' ownerghip of the present hydroelectrle plant treet, the Federat Gevernment controls the dam af te.

7. The constructilon of tihe Friagt: Raplda dam could create a crit1cal hazard to the Henford. Worka in ogae of enamy actilon. $\Lambda$ low dam, as proposed by the PUD, with more than one mile of earthafilit, would be ensier to breach than would the Corpa of Englneors' proposed dam, because of the gmaller crogagection of the earthmf11. The Cnrpa of Englneerg' dam, undar certaln circumatancas, could on the other hand have a far greater volume of water which would be released by breaching. Elther type dam would compound the digaster whloh would result, from breaching of Grand Coulee Dam (aee Hanford Clasa1cled Document Number 46604, subject: "Emergeney Flanning for Disaster at Grand Coules Dam, Dated September 25, $\left.1.952^{\prime \prime}\right)$

8. Recauge of the announced plang of the Mud for constructiton of the cam, and the antlofpated plans of the Corps of Englneers, the Commiar alon should decide at once whether 1t w11.1. offer objection to the congtruction of a dam at Priest Rapian.

\section{DISCUSSION}

9. Fertinent, dats on the dam, as proposed. by the Corps of Englneers In the "308 Report,", fol.tows: 


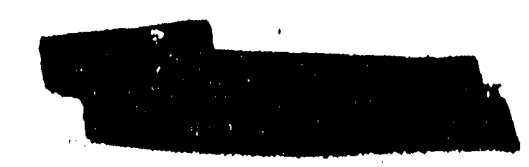

a. Type

: Concrate gravity, earth embankments on each side.

Crest : Concrete, E1. 597, Earth E1. 600.

River Bed : El. 395.

Norma.1 Pool.: Pil. 550 .

Pool Limits: Max. power surcharge to Fi. 555, drawn down to E.1. 540 when major flood 1s lmpendings filood control storage to Eil. 590 max.

Spl1.1.way

Crest: : E1. 5,32.

Storage : 1,800,000 Ao.Ft, to E.1. 555. 3,300,000 Ac. Ft. to El. 590.

Spl1.1way De-

a:Ln Flood : $1,400,000$ of 8 .

Operation : Normally headwater malntalned at elevation 550, but, except as noted below, when spring discharges exceed about 300,000 cfs., and. tallwater rises, surcharge ts to be added, up to elevation 555 at a discharge of about $52.8,000$ crs. However, in years when discharge at The Dalles are predicted to exceed 800,000 afs., the pool. w1.1.1 be drawn down to elevation 540 to provide maximum flond control atorago of $2,1.00,000$ acre reet, and discharge would be held as low as possibile while storing up to a maximum headwater elevation 590. Floods of ,800,000 cfs. or greater at The Dalles have an estimated fre. quency of once in 100 years on the regulated river.

b. The central, concrete portion of the dax i.s founded on bed rock at the approximate level of the existing stream bed about ele-vation 395. The masonry section consiats of a bay which will permit future construction of a navigation lock, a short non-overflow gravity section, a 1,400 foot spl.11way aection, a 2,200 foot powerhouse section, and another short non-overflow section. This te flanked on each slde by earth embankmentis, about 1,800 feet long on the rlght bank and about 7,000 feet long on the left bank. The ambankment has a 30 fnot crown at elevation 600 , with 1 on 2.5 slopes. Whenty-foot bemm are provided at the third points of tho down= 
Normal Pool.: El.. 550.

Pool Limits: Max. power surcharge to E1. 555, drawn down to E.1. 540 when major flood 1s impendings flood control storage to Eil. 590 max.

Spl11way

Creat.

Storage

1.1way De-

a:Lign Flood :

Operation :

: .1 .5 .32$.

: 1,800,000 Ao. Ft. to E.1. 555. 3,300,000 Ac. Ft. to EL1. 590.

$1,400,000$ ofs.

Normally headwatar malntalned at elevation 550, but, axcept as noted below, when spring discharges exceed about 300,000 of s., and tallwater rises, surcharge is to be added, up to elevation 555 at a discharge of about $528,000 \mathrm{cfs}$. However, in years when dis charge at The Dalles are predicted to ex.ceed 800,000 afs., the pool w111 be drawn down to elevation 540 to provide maximum filood control storage of 2,1.00,000 acre feet, and discharge would be held as low as pcsalb.le while storing up to a maximum headwater elevation 590. Floods of 800,000 cfs. or greater at The Dalles have an estimated fre.. quency of once in 100 years on the regulated river.

b. The central, concrete portion of the dax 1.8 founded on bed rock at the approxlmate level of the exlating stream bed about elevation 395. The masonry section consiats of a bay which will permit fature construction of a navigation lock, a short non-overflow gravity section, a 1,400 foot splilway section, a 2,200 foot powerhouse section, and another short non-overflow section. This is flanked on each side by earth embankmentis, about 1,800 feet long on the right bank and about 7,000 feet long on the left bank. The embankment has a 30 -foot crown at elevation 600 , with 1 on 2.5 slopes. Twenty-foot berms are provided at the third points of the downstream slope. Total thickness through the embankment at elevation 555 Is about 205 feet.

10. Most of the right embankment, and about half of the left embankment 1 les over bed rock at approximately elevation 395 , and those,

$$
-4-
$$

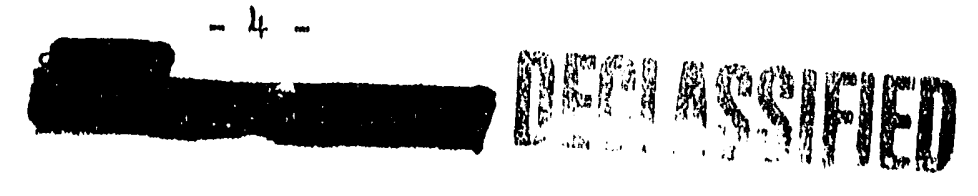




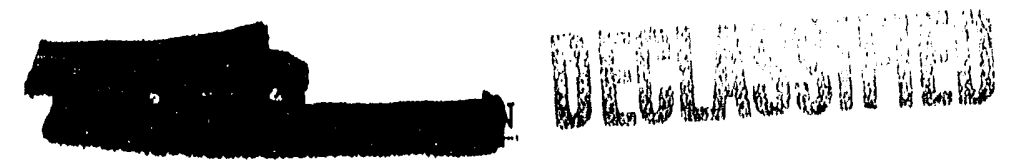

once breached, would probably quilckily erode to present atream-bed depth for a maxtmum width of about 5,000 feet.

11. Obvlously maximum artiflalal flooding would be caused with flood stage base dilscharges in the lower Columbla, and headwater at elevation 590. Ilowever, this combination of events is ao infrequent that Lts colncidence with enemy attack is belleved to be an unnecessarily severe assumption. It appenca that any attack would be timed during yearly high-water pertods, and that headwater of elevation 555, and bage discharge of $500,000 \mathrm{cfs}$ are reasonable assumptions.

1.2. The effect of breaching Erlest Raplds Dam under these condttions was Investigated using methods outilned in Corps of Engineers' report on Artificial Flooda In Columbla River, dated December 10, 195.1. Ta11water was estimated by extrapolation of Friest Raplds design curves, and comparison with computed rating curve at Vernitg for high discharges. It was assumed that the full thlckness of the ap1.1.1way aection could be breached down to elevation 395, and that the wldths of the breach would be three times waximum concretie thlckness at the bottom, and four times at the top. Discharge rating curves were computed by the Chanolne Wicket discharge methods descrlbed In above report, divided by 0.9 . The resultant outflows were soutied to Rlchland using the baslo values and methods ahown in the report. In the short subreach from the dam to Vernite halfhour time Increments were used, and two-hour Inarements in the balance. Slgnificant regults are tabulated below:

\begin{tabular}{|c|c|c|c|c|c|c|c|c|}
\hline Plant Area & $B$ & C & K & DiDR & H & $\mathrm{F}$ & 300 & Rlchland \\
\hline RLver Mile & 384 & 384 & 382 & 378 & 373 & 368 & $3 \lcm{45}$ & 338 \\
\hline Max. Flow, MLL1tion efs. & 3.1 & 3.1 & 3.0 & 2.07 & 2.5 & 2.5 & 2.1 & 2.0 \\
\hline Max.W.S. Elev。 & 4.50 & 450 & 4.45 & 440 & 435 & 4,32 & 395 & 387 \\
\hline Time after Breach, Creat & $3 \frac{1}{2}$ & $3 \frac{1}{2}$ & 4 & $5 \frac{1}{2}$ & 7 & 8 & $11 \frac{1}{2}$ & 12 \\
\hline Time after Breach unt1.1 Q $=$ & & & & & & & & \\
\hline $\begin{array}{l}1,000,000 \text { cfs. } \\
\text { River Purmp House }\end{array}$ & $1 \cdot \frac{1}{2}$ & $1 \frac{1}{2}$ & & 2 & $2 f$ & $2 \frac{1}{2}$ & $6 \frac{s_{2}^{2}}{2}$ & 7. \\
\hline $\begin{array}{l}\text { River Pump House } \\
\text { Plle Flonr }\end{array}$ & 4687 & 404 & 1,65 & 4.66 & $\begin{array}{l}409 \\
403\end{array}$ & 413 & $m-$ & $\cdots-$ \\
\hline Pile Pump House & 467.5 & 4.79 & $4+74$ & $467-D$ & 42.1 & 412.5 & $-\infty$ & $m--$ \\
\hline & & & & & & & & \\
\hline Lant & 4.53 & $\cdots$ & 459 & 4664 & +1.7 & & & $\cdots$ \\
\hline
\end{tabular}




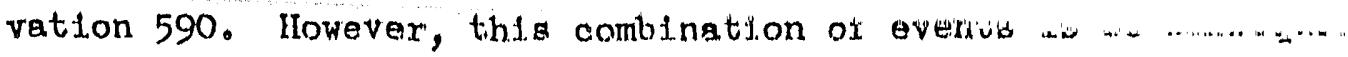

Its colncldence with enemy attack is belleved to be an unnecessarily severe assumption. It appears that any attack would be timed during yearly high-water pertods, and lhat headwater of elevation 555, and base discharge of $500,000 \mathrm{cfs}$. are reasonable asaumptions.

1.2. The effect of breaching Priest Raplda Dam under these conditions was Investlgated using methode outilined in Corps of Engineers' report on Artificial Flood.s In Columbla RLver, dated Denember 10, 1951. Tallwater was estimated by extrapolation of Friest Raplds design curves, and comparison with computed rating curve at Verntta for high discharges. It was assumed that the fullt thlckness of the apli.1way aection could be breached down to elevation. 395, and that the wlatha of the breach would be three times maximum concretie thickneas at the bottom, and four times at the top. Dlacharge rating, curves were computed by the Chanolne Wlcket alsoharge methods described in above report, divided by 0.9 . The resultant outflows were routed to Rlchlend using the baslo values and methods shown in the report. In the short subreach from the dam to Vernita halfhour time Increments were used, and two-hour Inorements in the balance. Significant results are tabulated below :

\begin{tabular}{|c|c|c|c|c|c|c|c|c|}
\hline Plant Area & B & $\mathrm{C}$ & $\mathrm{K}$ & $D=D R$ & $\mathrm{H}$ & $\mathrm{F}$ & 300 & Rlchland \\
\hline River Mile & 384 & 384 & 382 & 378 & 373 & 368 & 345 & 338 \\
\hline Max. Flow, MLLILon cfs. & $\begin{array}{l}3.1 \\
4.10\end{array}$ & 3.1 & $\begin{array}{l}3.0 \\
4.45\end{array}$ & $\begin{array}{l}2.7 \\
440\end{array}$ & $\begin{array}{l}2.5 \\
4.35\end{array}$ & $\begin{array}{l}2.5 \\
1,32\end{array}$ & 2.1 & $\begin{array}{l}2.0 \\
387\end{array}$ \\
\hline $\begin{array}{l}\text { The after Breach, Crest } \\
\text { Time after Breach unt1. } Q=\end{array}$ & $3 \frac{1}{2}$ & $3 \frac{1}{2}$ & 4 & $5 \frac{1}{2}$ & 7 & 8 & $11 \frac{1}{2}$ & 12 \\
\hline $1,000,000 \mathrm{cfs}$ & $1 \frac{1}{2}$ & $1 \frac{1}{2}$ & 2.m & 2 & $2 f$ & $2 \frac{1}{2}$ & $6 \frac{1}{2}$ & 7. \\
\hline Iitver Pump House & 427 & 427 & 4.25 & $4,1.9$ & 409 & 405 & $m-m$ & $a m \infty$ \\
\hline Plie Floor & 468.5 & 4,94 & $1+65$ & 1.66 & 423 & 4.13 & & $-m$ \\
\hline Plle Pump House & 4.67 .5 & 4.79 & 474 & $\begin{array}{l}467-D \\
4443-D\end{array}$ & 42.1 & 412.5 & $-\infty$ & $m-\infty$ \\
\hline Steam Plant & 4.53 & $-\cdots$ & 459 & 4,66 & $417 \cdot 5$ & 411. & & $-m$ \\
\hline
\end{tabular}

Crest stages shown would drown out all river pump houses by from twenty to twenty-seven feet and would nearly touch the " $B$ " steam plant. The 300 Area would be flooded to a depth of about ten feet, and the Rlohland levee would be overtopped by about twenty feet, Inundating the east half of the 


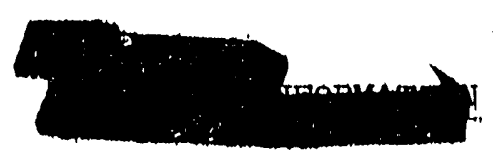

Village. Pasco and Kennewlok would also be very geverely flooded. The levee would be overtopped and appreclable damages within the plant area, Including drownlng of alli river pump houses, would oscur at stages of about 1,000,000 cfa, and as may be seen auch discharges would oscur constderably sooner than orest atages. The M1dway substation at Milie 390 , the present source of all Henford electric power, would be flooded in about thitry minutes of the dam fallure. The duration of discharges at or above $1,000,000$ efa. would sverage about fourteen hours, and "F" and "kn" pile floors would rempin below flood levels for about thirteen and ten hours, respectively.

13. It is estimaled that; about 2,000 gpm of cooling water would suffice, in emergency, for a abit down, hoaded plie after the firat few minutea. Water strred in earh area lis tabulated below, in millions of gallons:

Flant Area

Raw Water

Treated Water.

\begin{tabular}{|c|c|c|c|}
\hline $\mathbb{B}$ & C, & K. & $\mathrm{D}$ \\
\hline 25 & $\cdots \cdots$ & mis. & 25 \\
\hline 1.7 .6 & $2 ?$ & 16.5 & 1.7 .6 \\
\hline
\end{tabular}

$\mathrm{DR}$

H $\mathrm{F}$

$.17 .6 \quad 2 ?$

1.6 .5

1.2

2.5

$17.6 \quad 17.6$

of the stored treaten water, about 600,000 gallong in each area are in elevated tanks. Stored. raw water In a.l.h areas, except "K" Is connected to the export syatem, and in emergancy, water from this aystem could be fed to plie conling lines. Thus, with stored treated. water, the "B", "C", "D", and "DR" pliles can be cooled, if shut: down, for four days or longer, and there is sufficient raw water stored in "B" and "D" areas to feed "ll" and. "F", In emergency, for about elght; days, decreaged by the minfmum essential demand of the 200 armas. Inundated electric drive pumps would requitre geveral weeks to dry nut, but steam turbines could be put back into service falrily quickly, agsuming the river pump houses were not damaged severly structidraliy, There would be auffictent steam, within minutes after shut.m down, to arive the booster pumpa from the raw water reservolrs to the export lines.

14. Roastbly the dam could be breached more effectively by an attack 
siderably sooner than crest stages. The M1dway substation at Mile 390 , the present source of a.l. Hanford electric fower, would be flooded in about thirty minuties of the dam fallure. The duration of discharges at or above $1,000,000$ cfa. would average about fourteen hours, and "F" and "H" pile floors would remain below flood levels for about thirteen and ten hours, respectively.

13. It is estimated that; about $2,000 \mathrm{gpm}$ of cooling water would suffice, in emergency, for a shit down, loaded plle after the first few minutes. Water stored in egrh area is tabulated below, in militions of gallons :

\begin{tabular}{|c|c|c|c|c|c|c|}
\hline Plant Area & R & C & $\mathrm{K}$. & $\mathrm{D}$ & $\mathrm{DR}$ & II \\
\hline Raw Water & 25 & $\cdots \cdots$ & $\min$ & 25 & $-\cdots$ & \\
\hline Treated & .1 .7 .6 & 2? & 16.5 & 1.7 .6 & 1.2 & 1.7 .6 \\
\hline
\end{tabular}
Of the stored treated water, about 600,000 gallong in each area are in e'evated tanks. Stored. raw water in all areas, except "K" 1 s connected to the export system, and in emergency, water from this system could be fed. to pile cosling lines. Thus, with stiored treated water, the "B", "C", "D", and "DR" plifes can be cooled, if shut: down, for four days or longer, ana there 18 suffictent raw water stored in " $\mathrm{B}$ " and "D" areas to feed "H" and "F", In emergency, for about elght; days, decreased by the minimum essential demand of the 200 areas. Inundated electric drive pumps would require several weeks to dry out, but steam turbines could be put back into service fairly quickly, assuming the river pump houses were not damaged severly structirally. There would be alfficlent steam, within minutes after shut.down, to drive the boogter pumps from the raw water reservolrs to the export lines.

14. Poaglbly the dam could be breached more effectively by an attack on the left abutment. Assuming a breach could be blown more than fifty feet deep, across a 280-foot thickness, it would soon enlarge 1tself to an opening even larger than that assumed. The abutments are also vulnerable 
In event of breaching Coulee Dam to an opening on the order of the $1 \mathrm{~A}$ breach. Routing the $1 \mathrm{~A}$ flood to Frlest Raplda, and assuming all. aplliway and siluice gates open, Indicates that the dam would be on the verge of overtopping twenty hours after breaching at Coulee, with concurrent splilway dilscharge of $2,000,000 \circ f \circ$, and inflow into Frieat Rapida pool of 5,500,000 cfa. Shortily therageter the dam wolld be overtopped, and the earth embankments wouldi he quickly washed out. Feak inflow into the pool

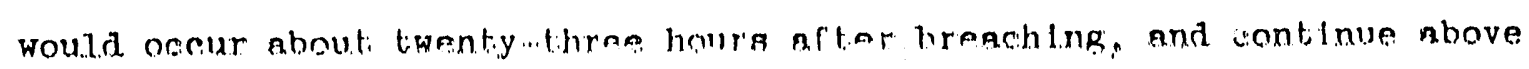
5,000,000 efs, until. about twentymgeven hours. The crest of the flood wave at Hanford would be delayed alightiy, buti lncreaser In slze.

1.5. The ghove is predicated on the "308 Report" propose1 particularm. 1.y with regard to the maximum ponl elavation 555 and the top of dam at elevation 597. Were 1t dectack to conatruct the dam and to operate 1 t at higher power pool levela " the flood wave regultidng from a possible breach by enemy action would be very much more severe. For inatance, with the pool level at 590 and the agme breach as dilacusaed above, the resultant flood wave crest: wolld be ten to twelve feet hlgher than that Indlcated in the table above. Sumb atigess wolld drown out the "Dr" plle pump house. The dam proposed by crant: County PuD for power production only would have a crest elevation of nnly 560 feet. Cross-gaction areas of both the concrete and earth-ufli1 gections would be correspondingly amalier. If this dam were to be bullt, 1. 1. belleved that the dam could be breached more easlily, the eroalon following breaching would be hastened and flood creat values shown ghove would be reached in ahorter lime.

16. Factors infiuencing AEC to permit the constiruction of Priest Raplds Dam:

a. The presentily proposed expansion program of Hanford Works w11.1 increase forecasted peak electrtc power demands from 1.31 MW to $275 \mathrm{MW}$. The proposed Friest Raplda Dam possesses certain obvious attractions as a surce of thits additional power, due to its loca- 
way discharge of $2,000,000 \mathrm{r} \%$, and inflow tnto Eriest Raplda pool of 5,500,000 cfs. Shortily theranfter the dam wowld be overtopped, and the earth embankments would be qujekly waghed out. Feak Inflow Into the pool would oscur about twenty ythras hourg aftar hreachlng, and cont lnue nbove 5,000,000 efs., untili about twenty yeven hours. The creat of the flood wave at Hanford would be delayed allghtily, but lncreaped in alze.

1.5. The above is predicated on the "308 Report" proposel particularm. ly with regard to the maximum ponl elavation 555 and the top of dam at elevation 597. Wore 1t; docidak tio construct the dam and to opexate 1 t at hlgher power pool levele tha filood wave reaulting from a pogalble breach by enemy action would be very much more severe. For inatanse, with the pool level at 590 and the agre breach as digcugaed above, the regultant flood wave cregt; would be ten to twelve feet higher than that indicated in the table above. Such atrges would daown out the "DR" plie pump houre. The dam proposed by Crrant Count:y PUD for power production only would have a crest elevation of' only 560 feetin Crosa-gection areas of both the concrete and earthmill afotions would be correspondingly amaller. If this dam were to be bullt, 1t 1 s balleved that the dam could be breached more easlly, the erosion following breaching would be hastened and flood crest values shown above would be reached in ahorter time.

16. Factors Infiluencing ArC to permit the conetiruction of Prieat Raplds Dam:

a. The pregentiy proposed expansion program of Hanford Works w11. Increase foresgated pogk electric poler demands from $131 \mathrm{MW}$ to 275 MW. The proposed Frlest Rapldis Dam posesesea certain obvious attractions as a anuree of thle additionsil power, due to 1 ta locam tion a short distance from the reators, and an even ahorter distance from the Midway Substation from whieh the reactiors now get their power. Refexenced "308 Report" Blves the project a nominal prime 


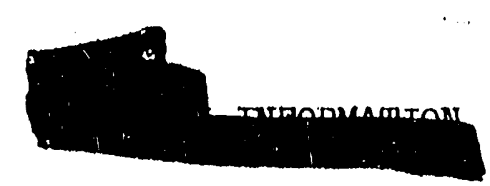

capablilty of $795 \mathrm{MW}$ and, under operation integrated with certaln other Columbla Bagin planta, an ultimata nominail flrm capabli1ty of $1,010 \mathrm{MW}$ at $75 \%$ lond. factor. Frleat Raplde would thua be capable of supplying all. Hanford demanda, an well ag maklng aubatantial additional contirlbution tin the Northwegt power pool. Direct connection Into the works power lopp through a relatively short (10 to 1.2 mileg) tranamigsion lina should sagure servles of high quality at low cost.

(1) Fower now in bronght: to Midway subatation on long trangmigelon linen from Grand Coules Dam, Bonnevilie Dam and from the varloug other gonresa of the Northwest power pool. McNary Dam, lo alrilne miles to the enuth of Midway Station, w111 go into power production in 1954, but the Bonnev 11.1. Dower Adminfetration apparentily hopes to use much of this power in a new loop extending into Oregon Crom MaNary Dam. Midway Substiation lo only six and onewhalf mlles below the Priagti Rapida Dam site and in turn is five and one-.half milea above plant, 100,B. A direct line from Friegt Raplds tio the

1 Hanford Worka for emergency power, would be easy to bulld and to maintain.

b. A request that Prtast Raplra Dam ennetruction be deferred or abandoned would cregte a serinus publle relations problem in the Northwest for the follow lng reagent:

(1.) I'his would. sarlously dis arupt the Corpe of Ing ineers filond control program on the Columbia Rlver, alnee the Englnears at:ate that; both Iohn Day and Priegt Raplda Dama are easential to the flond contirni plan and that no alternates are known.

(2) There 1. no organized opposition to the Frlegt Raptds Dam. The fiah interest:s (and probably the ralinoads) 
ditional contribution to the Nortihwest power pool. Direct connection Into the works power loop through a relatively short (10 to 1.2 miles) transmigston lina should aggure servfce of high quality at low costi。

(1.) Fower now in bronght: io MIdway Subatation on long trangmigalon linas from Grand Coldee Lum, Bonneville Dam and from the varlous other somress of the Northwet power pool. MoNary Dam, lo alriline miles tin the soluth of Midway station, w111. gn Into power production in 1.954, but the Bonnevili.e Power Adminletration apparentily hopes to use much of this power in a new lnop extend.lng into Oregon from McNary Dam. Midwgy Subgtiation fa only alx and ona half miles below the Prifagt Raplda Dam siten and in turn is five and onewalf miles above plant; 10n $\mathrm{B}$. A ditrect line from Friest Raplds to the

1 Hanford Worka for emergency power, would be eagy to bulld and to maintilin.

b. A requagt: that Priagt; Raplda Dam construction be deferred or abandoned would create a garloug publice relations problem in the Northwest for the following reasons:

(1.) 'I'his would saxtously disrupt the Corpe of' Engineers flinod control program on the Columbla Rlyer, alnee the Englnears atwle that: both wohn Day and Frleat: Raplda Dama are eaaentilal. to the flond rontrni p.lan and that no alternates are known.

(a) There ta no organized opposition to the Frleat Rapids Dam. The fiah interest:o (and probably the ralitroads) have offered aluceseful oppostition In Congress to the lower Snake Rlver damg which could produce much addltional power for the Factifo Northweatio Slnce the Columbla Rlver above Prieat

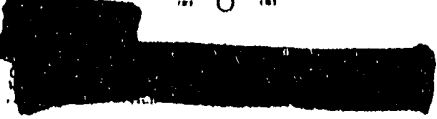




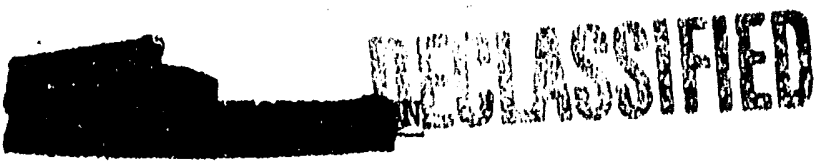

Raplds 1 s of less slgniflcance to commerolal fishing than is the Snake River above Ice Harbor, it la doubtful that the flsh Interests would be as active as they have been in connection with Ice Harbor Dam.

(3) The proposed PUD construction would be finunced largely by private money. AEC opposition could be interpreted as a phase of Federal opposition to private financing of these major power factiltilea. Such charges now are being levelled at the Government wlth regard to the proposed Hell's Canyon Dam on the Snake, because of the opposition of certain federal. agencies to the proposal of the Idaho Power Company to bulld several low head dams in place of the hlgh Hell.'s Canyon Dam.

(4) The Prlest Raplds Dam would reduce the necessity for llanford's power belng brought over long transmisaton IInes at all times. Blinllarly, transmiasion Into the Columbla Basin Irrigation development could be shortened.

(5) Loss of the Priest Raplds oapacity could diminish the Industrial development of the state of Washlngton. Governor Arthur Langlie of the State of Washlngton recently suggested publicly that the Prlest Rapids Dam be constructed at this time In lieu of the controversial Ice Harbor Dam. Information from officiala of the Bonnevilie Power Administration Indicates that its currently authorized expansion was predicated. on and belng bullit only for electrical power demands of normal. Industrial and private oonsumers. The Hanford expansion program was not taken into consideration. Uniess BPA gets new generation, in addition to that currentily authorized, the Hanford demand would neceasar1ly be withdrawn from other power users In the regton. (Memo dated August 29, 1952, David F. Shaw to R. W. Cook; also, letter from Gordon Dean, Chairman of 


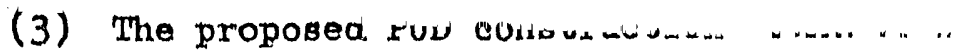

largely by private money. AEC opposition could be Interpreted as a phase of Federal. opposition to private financing of these major power faclitties. Such cherges now are being levelled at the Government with regard to the proposed Hell's Canyon Dam on the Bnake, because of the opposition of certain federal agencles to the proposal of the Idaho Power Company to bulld Beveral low head dams in place of the high Hell's Canyon Dam.

(4) The Prlest Rapldis Dam would reduce the necessity for Hanford's power belng brought over long transmission IInes at all times. Blmliarly, tranamisaton Into the Columbla Basin Irrlgation development could be shortened.

(5) Ioss of the Priest Rapids oapacity could diminish the Induatrlal development of the state of Washlngton. Governor Arthur Langl.1n of the State of Washingtion recently suggested publicly that the Friest Raplda Dam be constructed at this time In Ileu of the controversial Ice Harbor Dam. Information from offletals of the Bonnevilie Power Admlnistration Ind1cates that its currently authorlzed expansion was predicated. on and belng bullt only for electrical power demands of normal. Industrial and private consumera. The Hanford expansion prom gram was not taken Into consideration. Unless BPA geta new generation, In addition to that currently authorlzed, the Hanford demand would necessar1ly be withdrawn from other power users In the region. (Memo dated August 29, 1952, Dav1d F. Shaw to R. W. Cook; a.so, letter from Gordon Dean, Chatrman of AEC, to Oacar L. Chapman, Secretary of Interlor, dated October 29, 1952 and rep.ly thereto dated December 5, 1952.)

17. Other national defense efforts in the reglon w111 ouffer if more dama are not bulit. Aluminum reduction plants and other Industrles

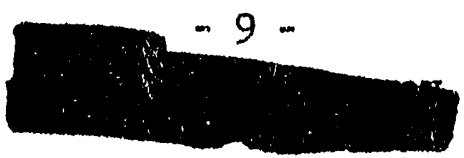




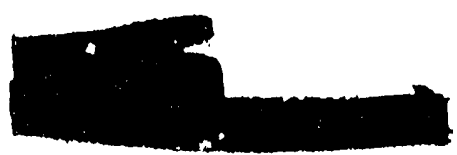

wth contracts for Interruptible power have been compelled to reduce or close down this winter, as they also were last winter, because of lack of electrical power. Rven large industrles with firm power have been comm pelled to reduce consumption by $10 \%$. Fower production 1. low because of lack of water. Additional dams would partially remedy this sltuation, since they would atore water for generation and for orderiy release to the dams below.

18. Diking mlght prove feasible in protect the Hanford plants: against damage from a breach of the dam. Such protection presentiy is beIng considered in regard to the poasible breaching of the Grand Coulee Dam, but the effectiveness of such protiection cannot be guarantieed.

19. Factors influencing AEC to object to the construction of Prlest Raplata Dam:

a. The estimated completion date, seven to ten yeara hence, would come too late to serve $A B$ a source of power at the time of Hanford's Increased needs as presentily programmed.

b. The dam potentitally could cause disastrous damage to the iW and the entire Trimlty area In the event of successful enemy efforts to breach elther this dam or the Grand Coulee Dam, or both.

c. The long, earth-fllied portions of the dam are partioularly susceptible to bomb damage, because the exoling action of the water could be triggered by relatlvel.y litght bomblng.

d. The feasibility of diking the various plant areas against the maxlmum calculable flond crest (Grand Coulee breach on top of Prlest Raplds breach), fa open to question at present.

e. Inareasing regional power requirementa can be met by conatruction of varlous other proposed dama on the Columbla and Snake rivers, leaving Priest Raplas as the last dam to be construoted, if 1t 1 s to be constructed at all. 
lack of water. Additional dams would partially reinedy this altuation, olnce they would atore water for generation and for orderly release to the dams below.

18. Diking might prove feastbile to protect the Hanford plants : against damage from a brasch of the dam. Such protection presentily 1 s beIng considered In regard. to the posalble breaching of the Grand Coulee Dam, but the effectivenes of such protiaction cannot be guaranteed.

19. Factors Influencing AEC to object to the construction of Prlest Rapida Dam :

a. The estimated completion date, seven to ten years hence, would come too late to serve as a source of power at the time of Hanford's Increased needs as presently programed.

b. The dam potentilally could cause disastrous damage to the HW and the entire TrlmClty area in the event of successful enemy efforts to breach elther this dam or the Grand Coulee Dam, or both.

c. The long, earth.fliled portions of the dam are partioularIy susceptible to bomb damage, because the eroding action of the water could be triggered by relatively light bombing.

a. The feasiblilty of diklng the various plant areas against the maximum calculable flond crest (Grand Coulee breach on top of Priest Raplda breach), ta open to question at present.

e. Increastng reglonal power requirementa can be met by conatruction of vartous other proposed dams on the Columbla and Snake rivers, leaving Priest Raplds as the lagt dam to be construoted, if It Is to be constiructed at all.

\section{CONCLUSIONS}

20. It 1s conaluded that:

a. The prinolpal potential hazard In Prieat Raplda Dam 1Les $\ln 8$ $-10=$ 
(1) Its susceptiblifty to enemy action, or

(2) Its susceptibility to erosion in osse Giand Coulee Dam suocessfully wore breached by enemy action, assuming that breaches of the magnltudes described by the Corps of Englneers' report are possible.

b. The fact that much of the total length of the Priest RapIds Dam would be earthinfliled, subject to relatively easy breaching and rapld erosion, inoreases the downatream disaster potential to both the IIW plants and the TrimCities area.

c. In event of a breach, the warning time would be barely sufficlent to evacuation of personnel and would require instantaneous shutdown of the plantis.

d. While the Priest Replda Dam would furnish to the IIW a nearby source of direct power at favorable cost, it lo not at present ersential to the HOO or to the Pactiflc Northwest, since the other proposed dama, four of whlch are now authorlzed, could be constructed to provide the necensary power. The four authortzed lowhead dams on the Lower Snake, and the John Day dam, at mille 220 on the Columbla, would provide more total power than would the priest Raplda Dam.

\section{RECOMMINDATION}

It is recommended that the AEC:

a. Authorlze the IroO to advise the Corps of Englneers, the Governor of the Statie of WaghIngton, Grant County Publito Utility Distriat \#2, the Bonnevilie Fower Admintatration and the public that the Commissiton objects to the construction of the Prlest RapIds Dam at any time in the relatively near future. 
neers' report are posalble.

b. The ract that mucl of the total length of the Priest Rapm Las Dam would be earthifl1.led, subjeot to relatively easy breaching and rapld erosion, Inoreases the downstream disaster potential to both the HW plants and the TrimClties area.

a. In event of a breach, the warning time would be barely ouffiolent to evacuation of personnel and would require instantaneous shutdown of the plantis.

d. While the Prisat Raplas Dam would furnish to the IIW a nearby source of direct power at favorable cost, it is not at present essential to the HOO or to the Paciflo Nor thwest, since the other proposed dams, four of whlah are now authordzed, could be constructed to provide the necesary power. The four author1zed lowhead dama on the lower Snake, and the John Day dam, at mile ?20 on the Columbla, would provlde more total power than would the Priest Raplda Dam.

\title{
RECOMMIINDA'ION
}

It is recommended that the AEC:

a. Authorlze the ItoO to advise the Corps of Englneers, the Governor of the Statie of Washington, Grant County Public Utiltty Distrlat \#2, the Bonnevilile Fower Adminiatration and the publio that the Commisaton objects to the construction of the Priest RapIda Dam at any time in the relatively near future.

\section{DISCLAIMER}

\begin{abstract}
This report was prepared as an account of work sponsored by an agency of the United States Government. Neither the United States Gr:iumment nor any agency thereof, nor any of their employees, makes any warranty, express or implied, or assumes any legal liability or responsibility for the accuracy, completeness, or usefulness of any information, apparalus, product, or process disclosed, or represents that its use would not infringe privately owned rights. Reisrence herein to any specific commercial product, process, or service by trade name, trademark, manufacturer, or otherwise does not necessarily constitute or imply its endorsement, recommendation, or favoring by the United States Government or any agency thereof. The vlows and opinions of authors expressed herein do not necessarily state or reflect those of the United States Government or any agency thereof.
\end{abstract}





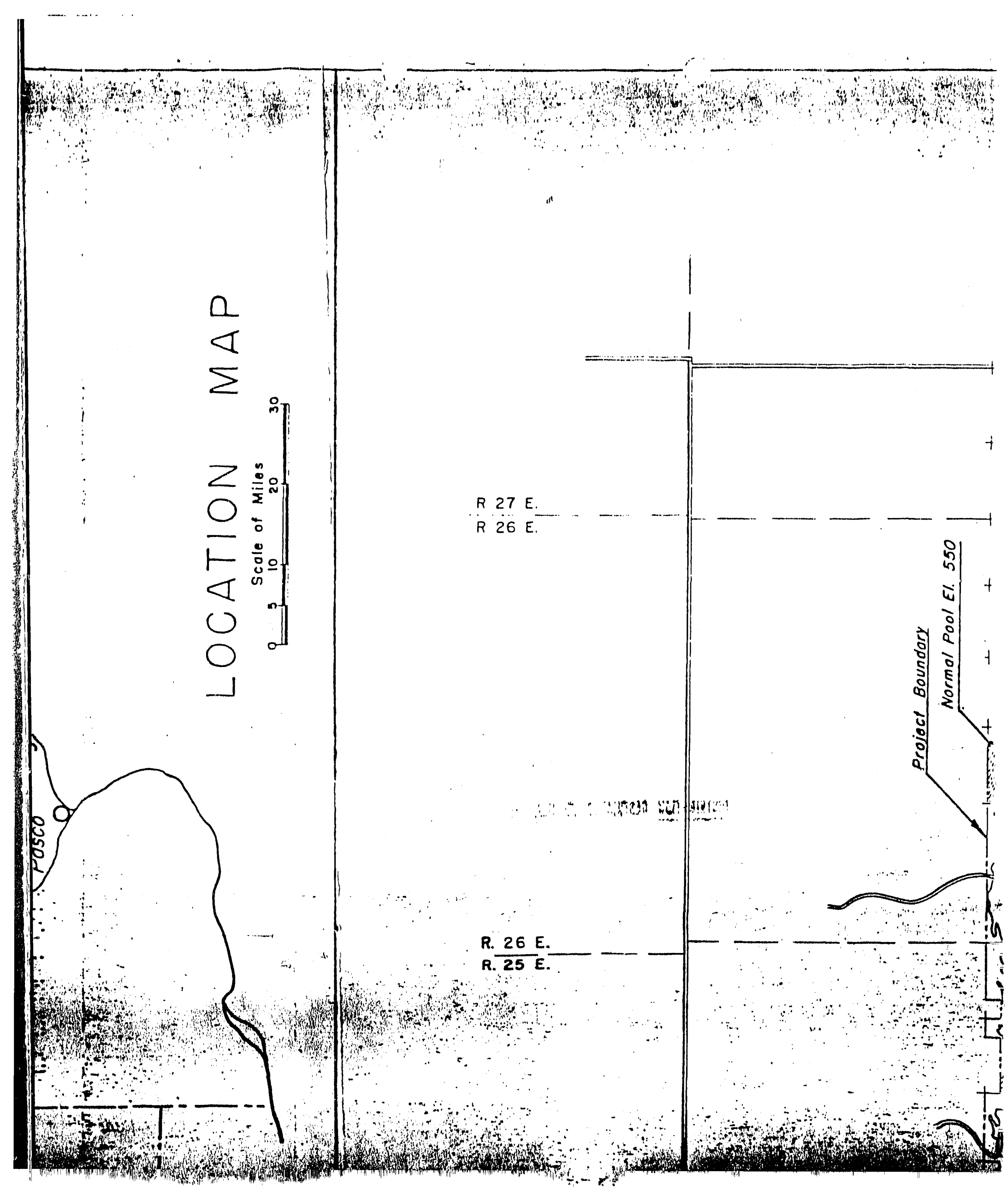





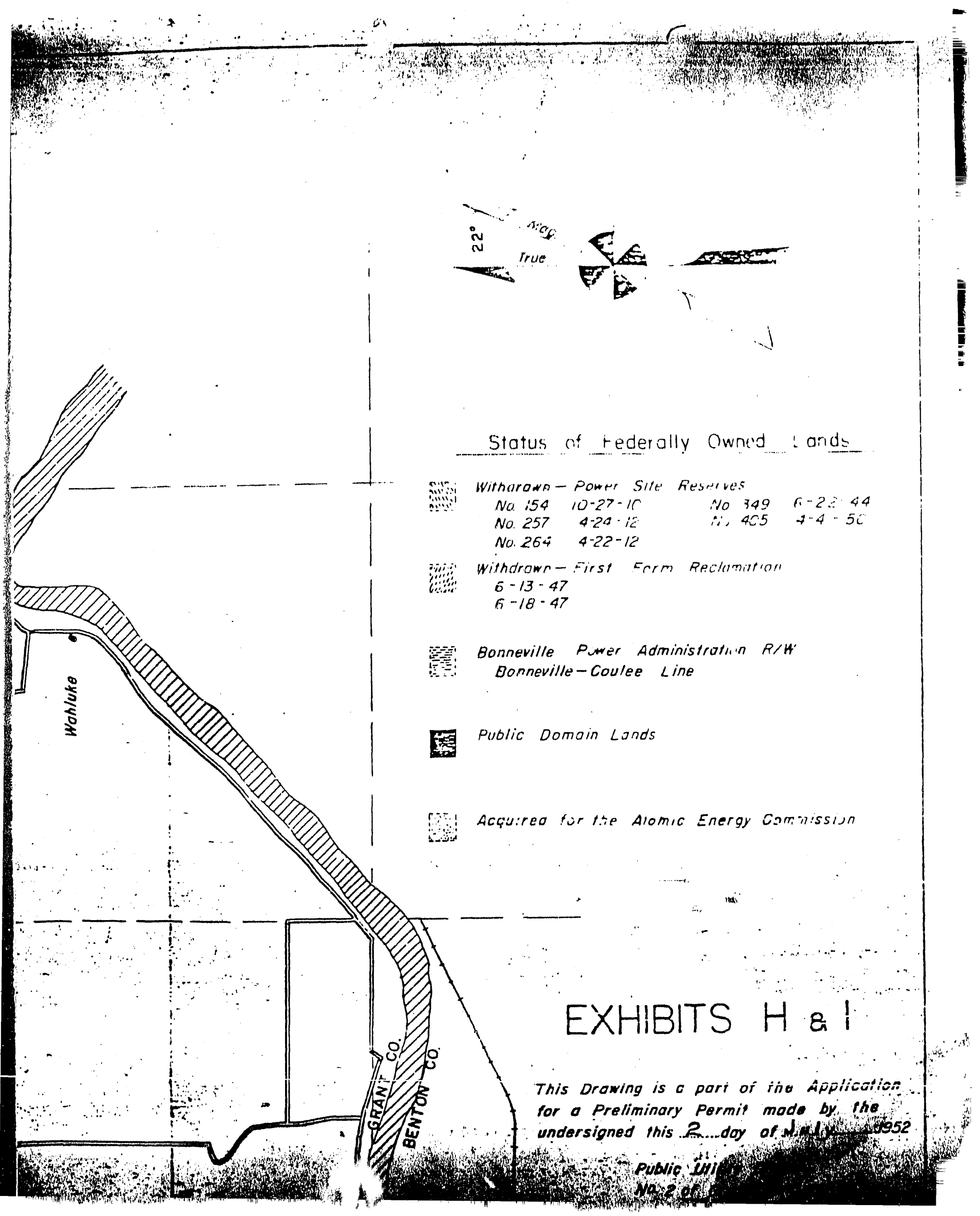




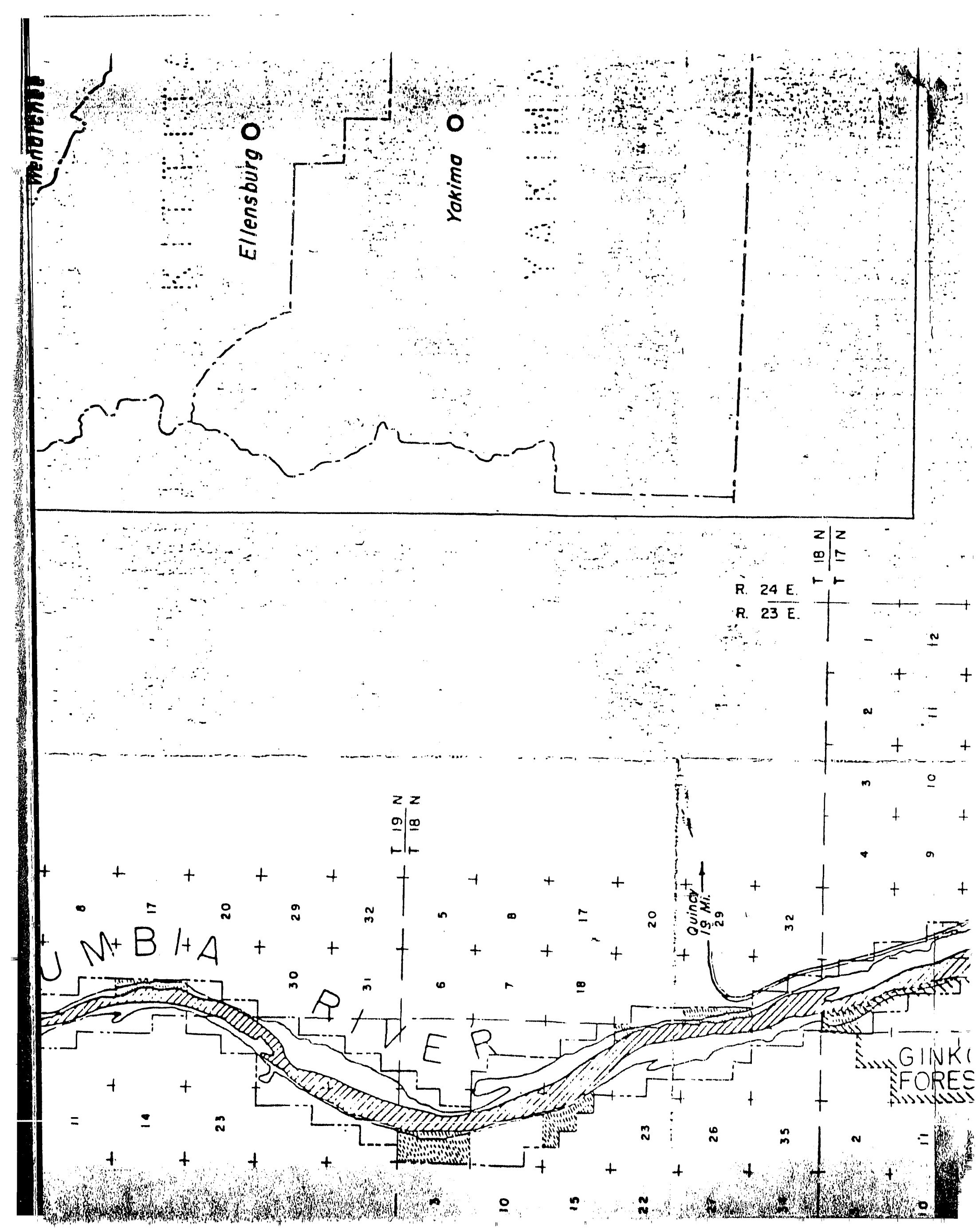




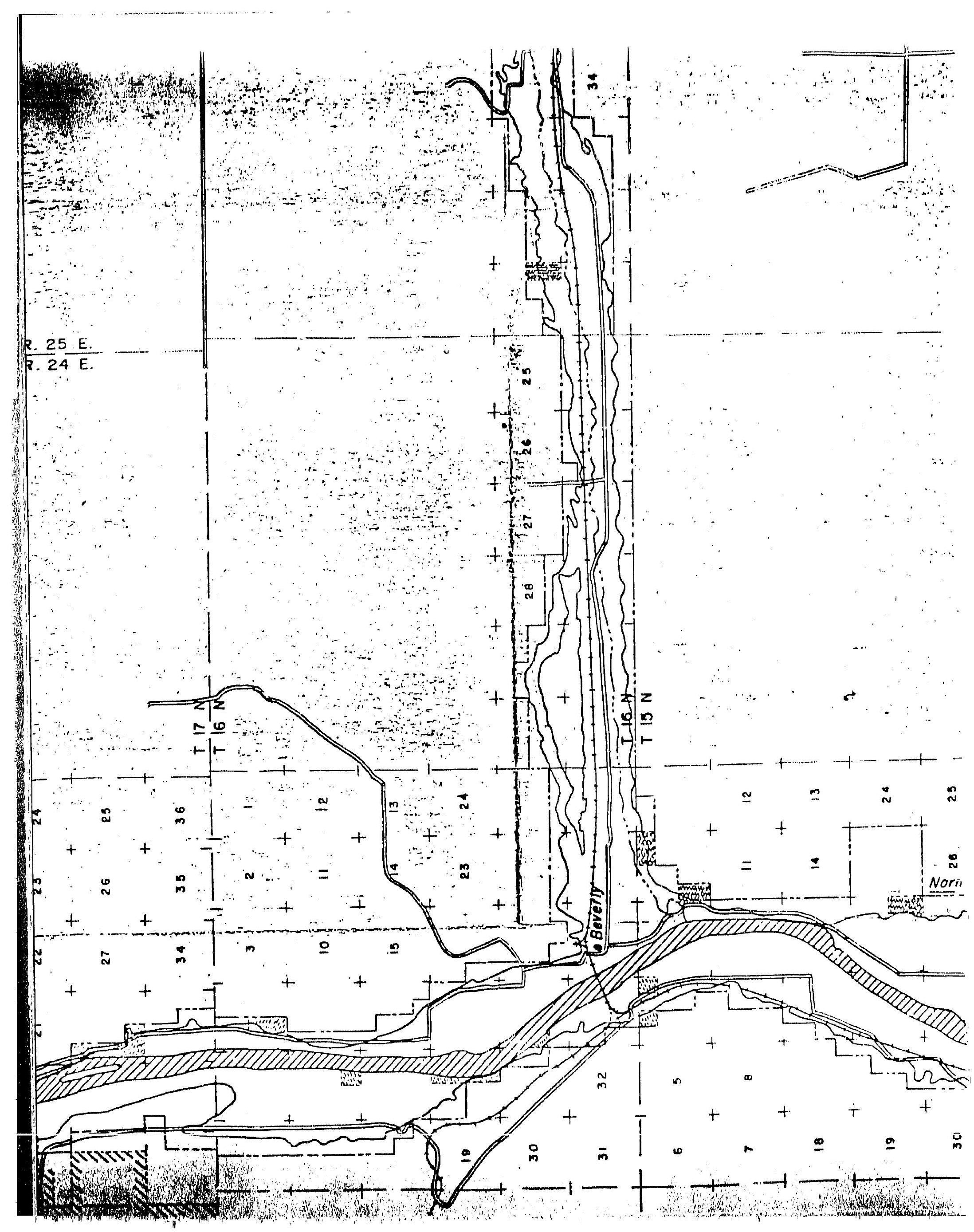




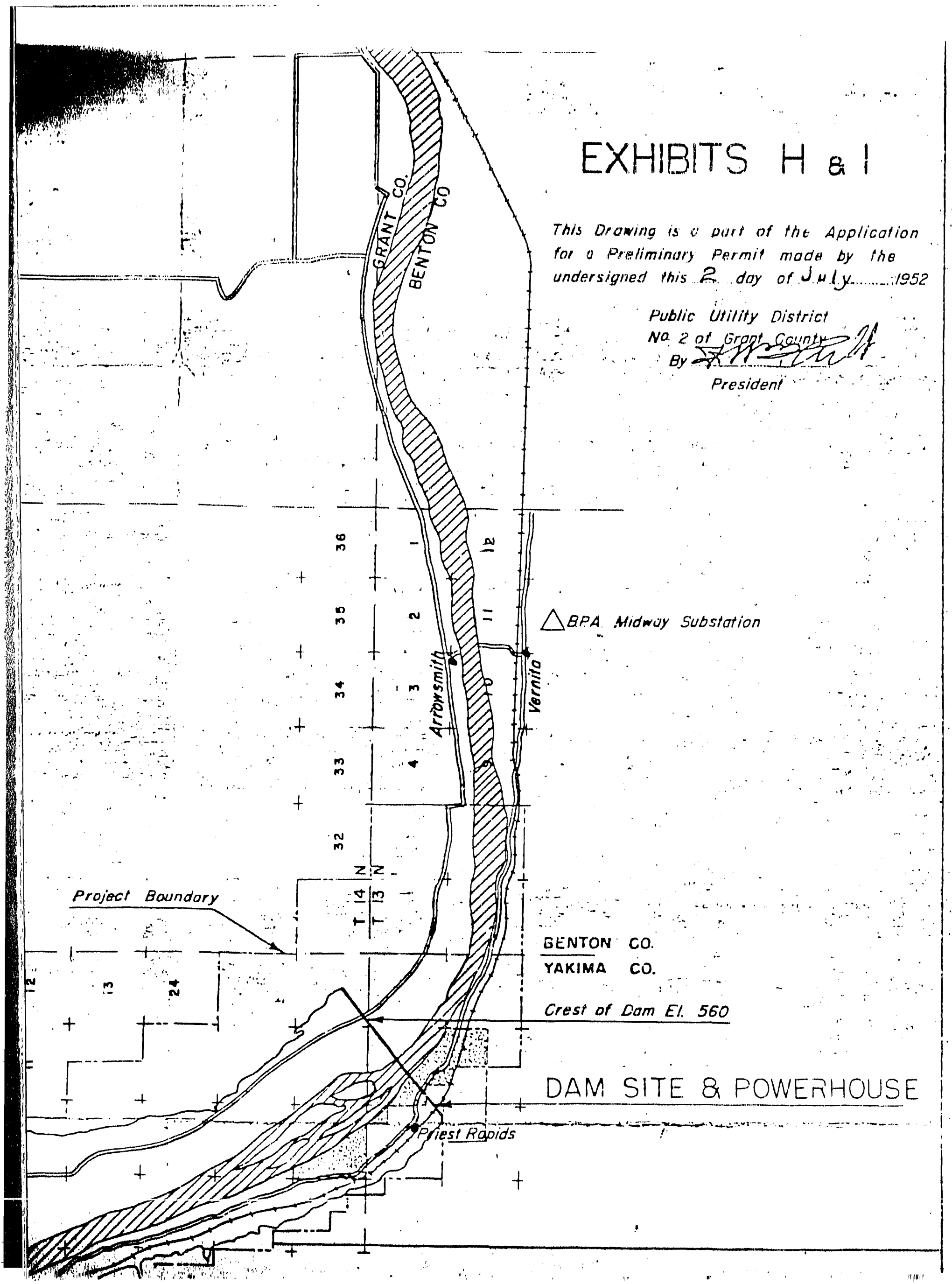




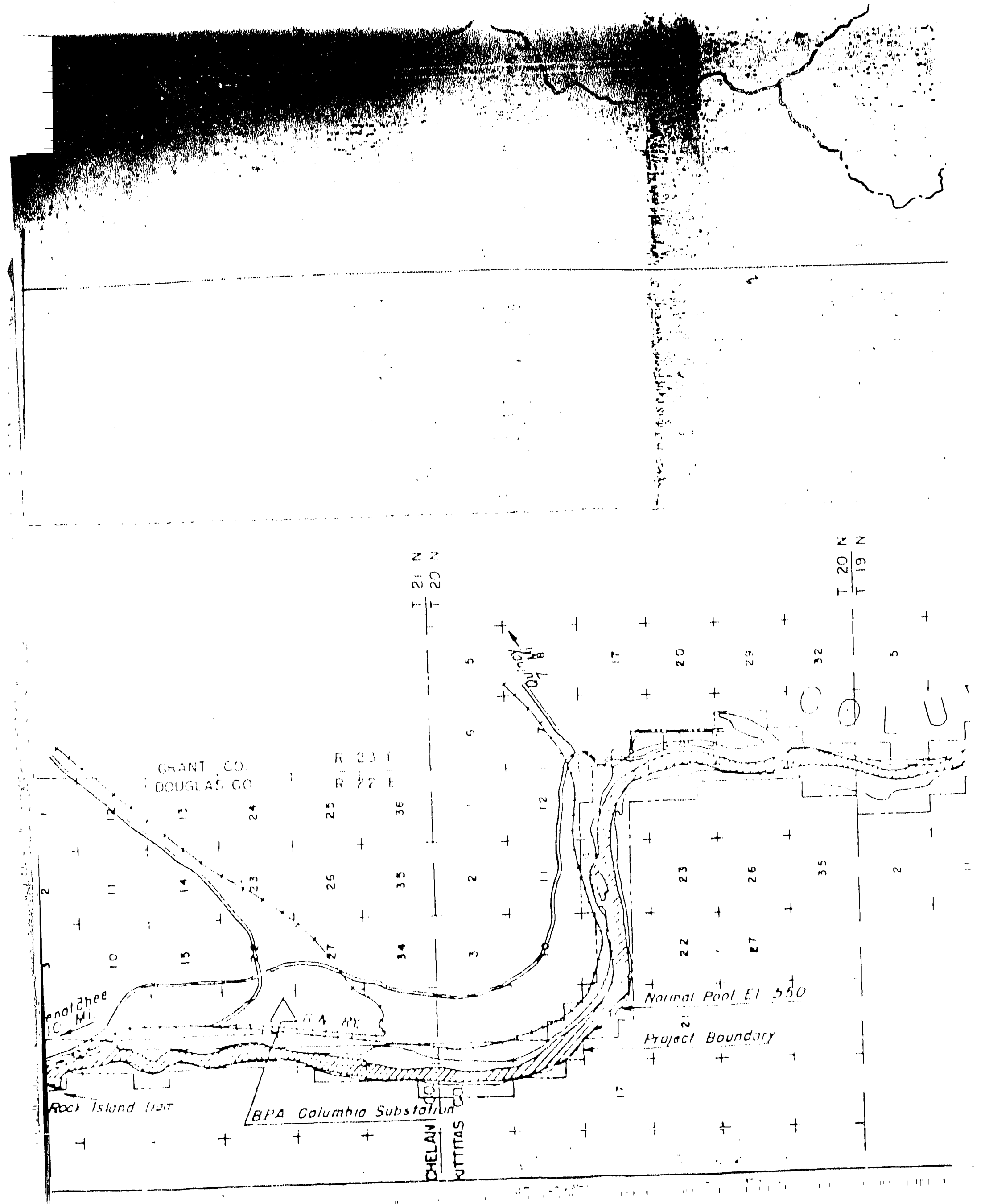




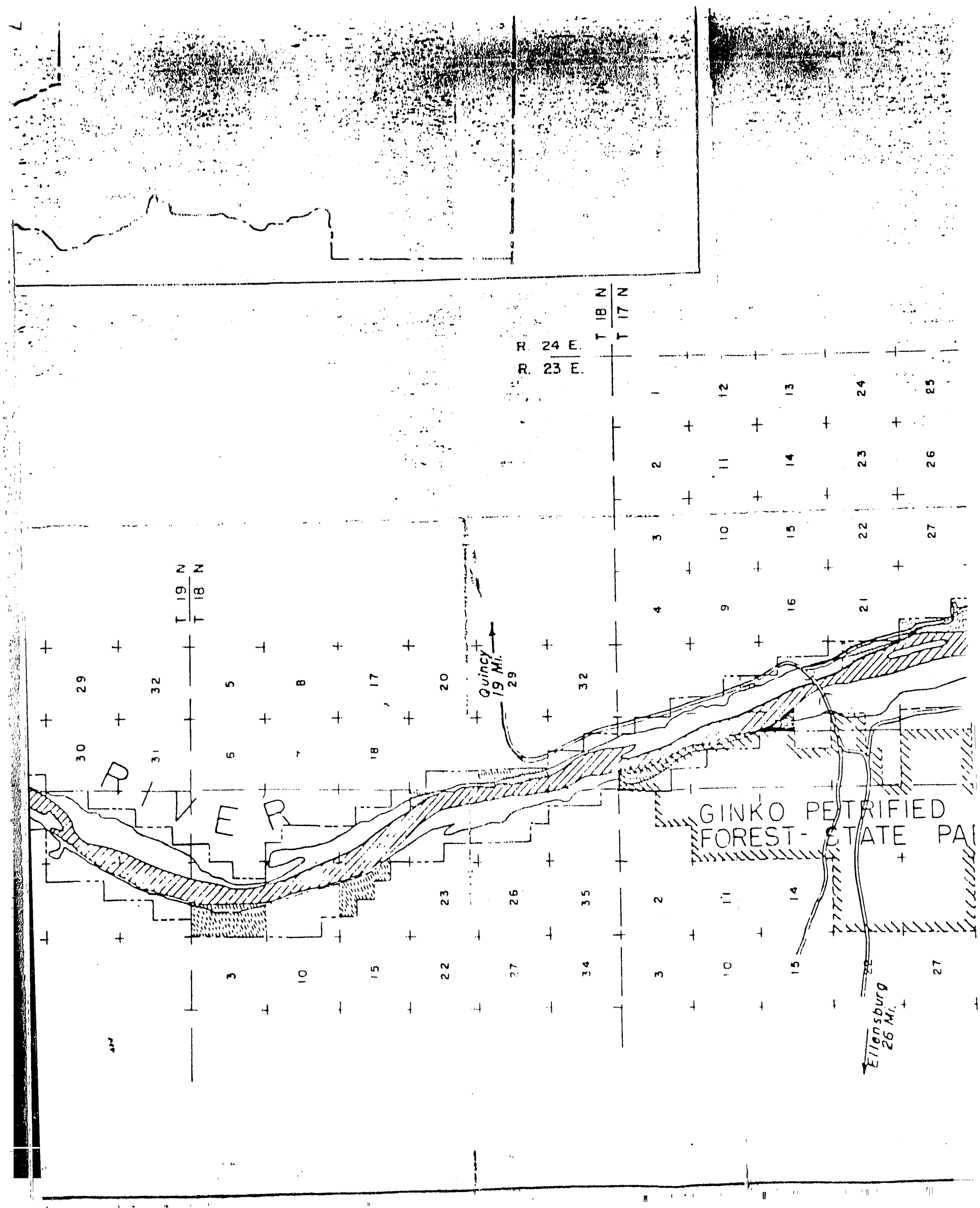




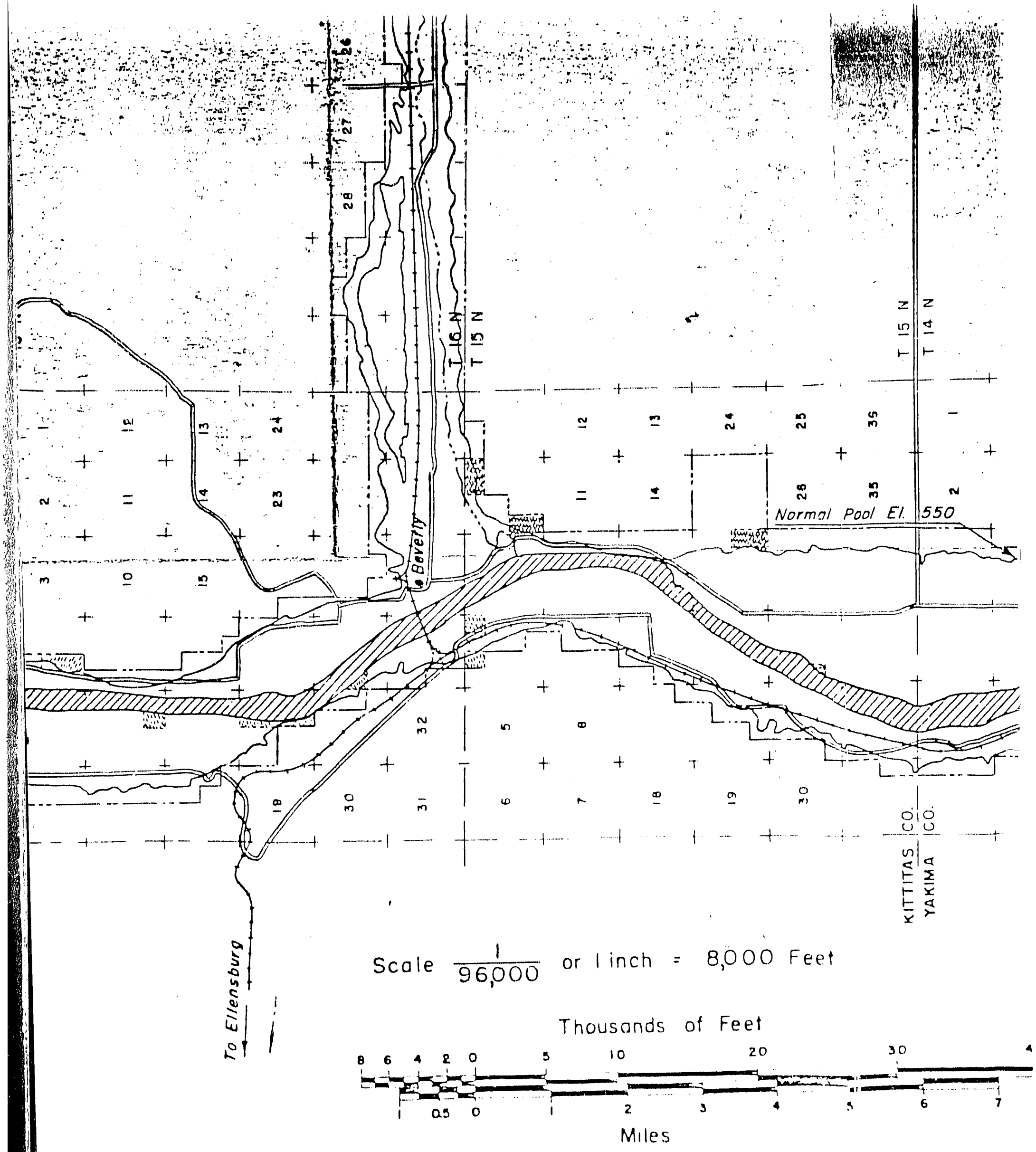




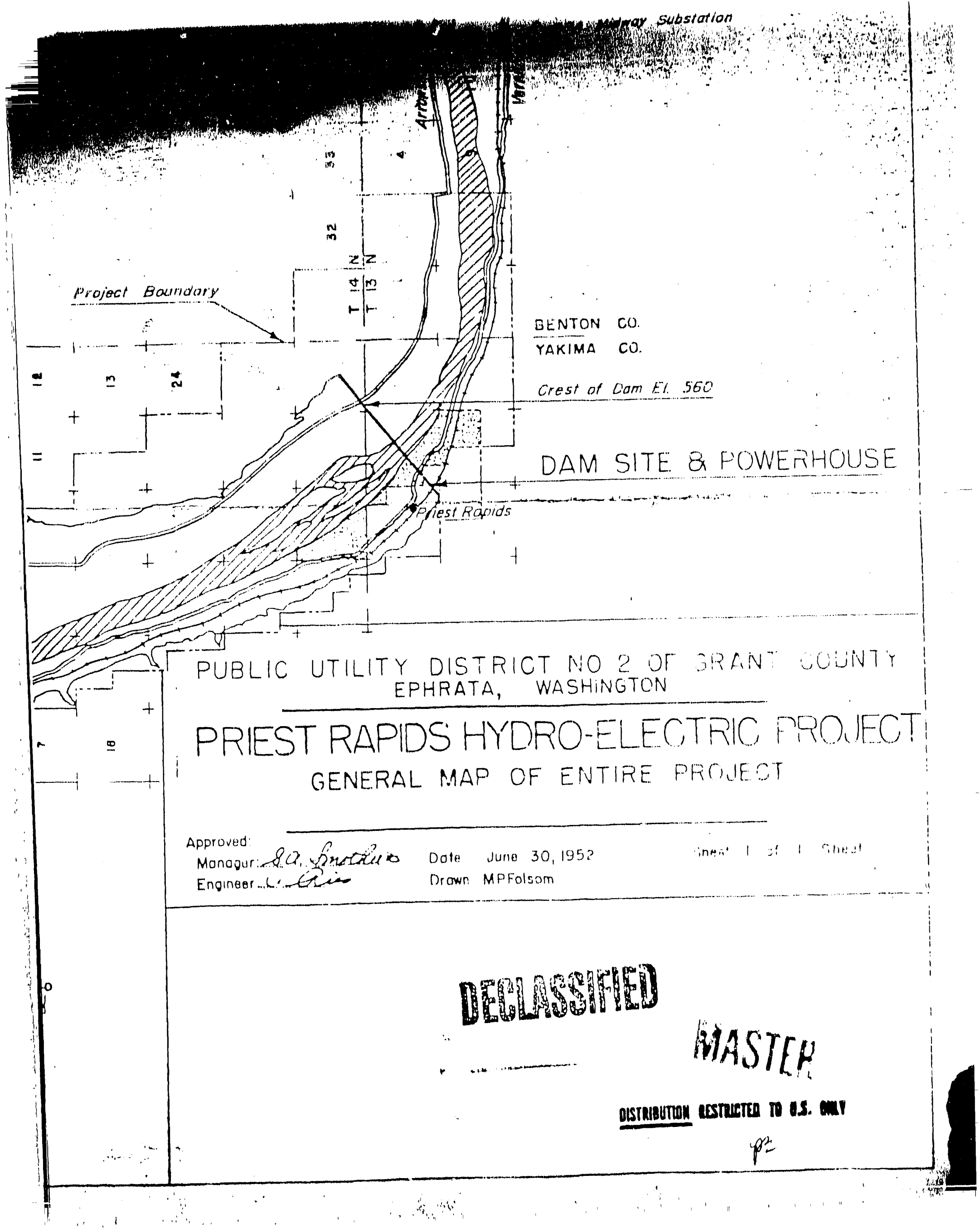



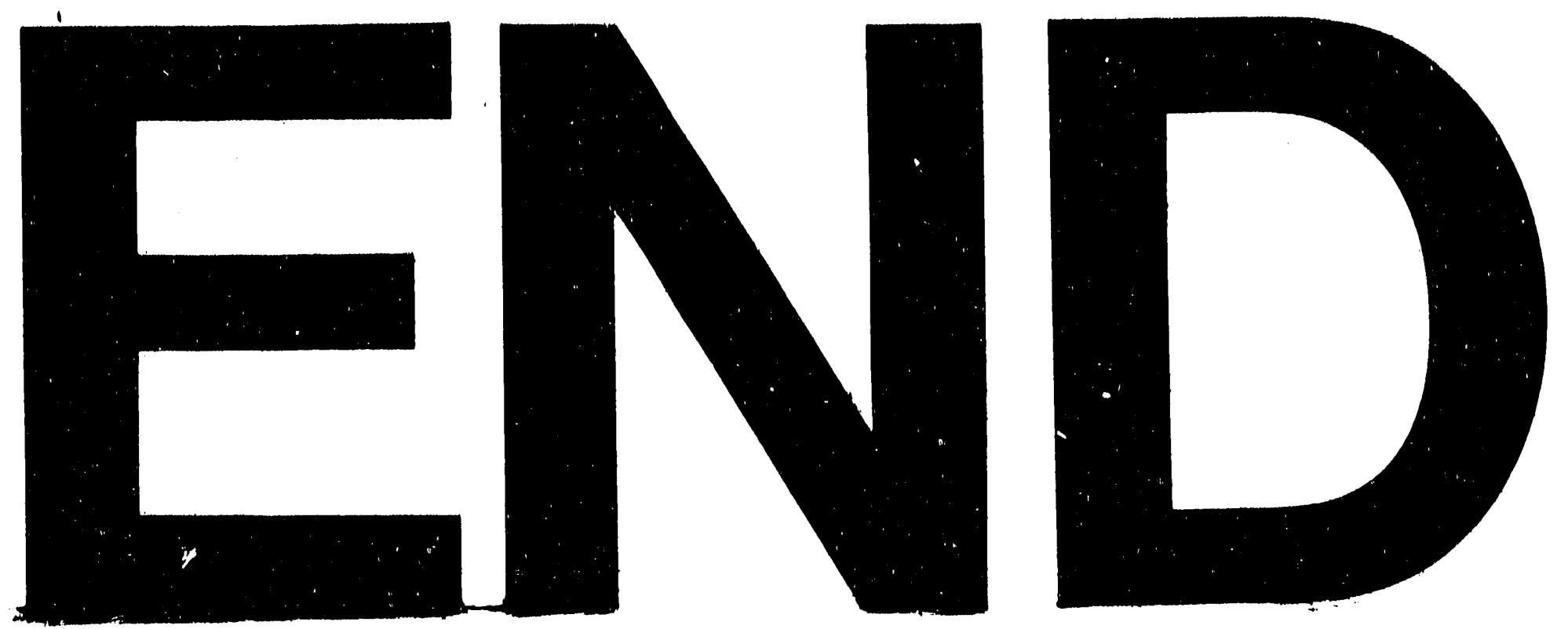

(1)
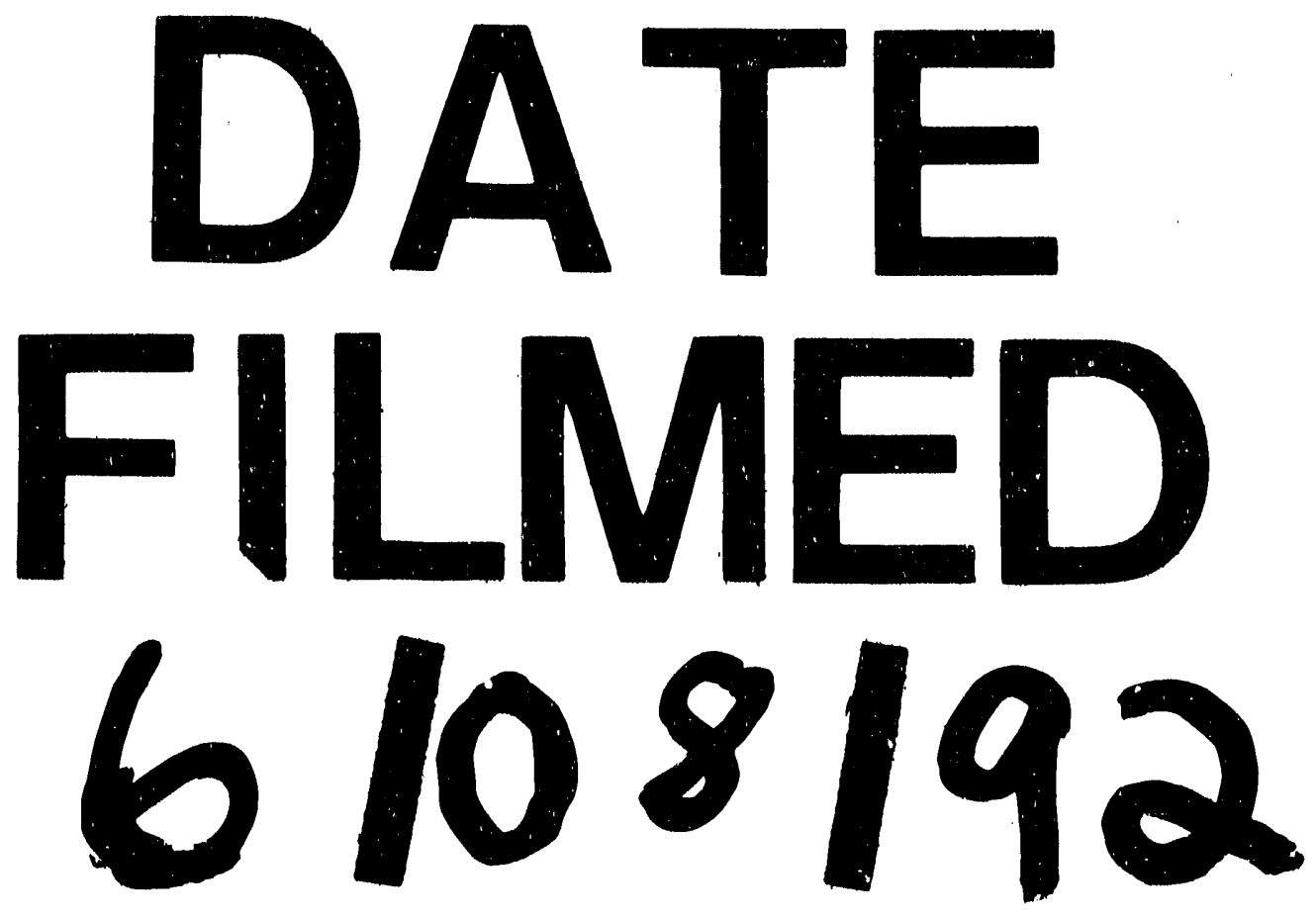
